\title{
Construction of Internet Financial Personal Credit Investigation System under the Condition of Big Data
}

\author{
ZUO Xiangli \\ Wuhan Business University, Wuhan, 430056, China \\ E-mail: 1165196272@qq.com
}

Key words: big data, Internet finance, personal credit investigation system, system construction

\begin{abstract}
This paper analyzes the current development status and problems of the existing credit investigation system in China, which based on the research methods of literature review and case study. And this paper subsequently sums up available experience of Chinese personal credit investigation system construction according to American ways. In accordance with the above analysis and the construction modes of Internet financial personal credit investigation system in the mainstream countries in the world, this paper puts forward one ideal mode suitable for China's national conditions, which can provide new methods and ideas to build Internet financial personal credit investigation system in China.
\end{abstract}

\section{Introduction}

Compared with other developed countries in Europe and America, the development of credit investigation industry in China started late and lags behind with only 20 years of exploration. Internet finance has been developing rapidly in China. Whether it is third-party payment, P2P lending or online finance, it is constantly changing people's living habits, but at the same time, the credit default problem that emerged during the development of Internet finance is hindering its further development. [1] At present, the main framework of personal credit investigation system in China is one built by the People's Bank of China under the leadership of the government whose credit evaluation is based on traditional offline credit data, lacking corresponding mechanism of internet online personal credit. [2]

The appearance of companies which use big data for credit collection such as Sesame Credit provides new methods to solve the problem of Internet authoritative personal credit. [3] Technology condition has been fulfilled in using big data for Internet financial personal credit investigation. Currently, the Sesame Credit points from Sesame Credit Company to some extent reflect the personal credit conditions of some Internet users.

\section{Internet Finance is the Driving Force of the Personal Credit Investigation System}

\section{The Development of Internet Finance Provides A More Comprehensive Solution to the Improvement of Personal Credit Investigation System}

In collecting personal credit data, compared with the traditional offline collection technology, Internet finance uses Internet-related technologies with which data collection scope is more extensive, the types of collection are more comprehensive, the collection speed is faster while the collection cost is lower; in the coverage of people, the traditional personal credit investigation system covers only $30 \%$ of the total population of society, while the Internet finance pays more attention to establish personal credit files to the long tail part of the population, in contrast, the coverage of people with personal credit data has further expanded.

The Development of Internet Finance has Given Birth to the Market-based Development of Personal Credit Investigation Services

The development of personal credit investigation service in China has always been based on the People's Bank of China which has some shortcomings such as the narrow source of personal credit 
data and the lag of updating. [4] In recent years, the People's Bank of China has also seen the impact that Internet finance put on the personal credit investigation system. Therefore, at the beginning of the year, it issued a "Notice on Doing a Good Job of Personal Credit Investigation", in which the People's Bank of China required that Sesame Credit Management Co., Ltd. and other eight credit agencies to carry out preparatory work for personal credit business, which indicates that the development of China's personal credit business market started.

\section{The Development of Internet Finance has Prompted the Sharing of Personal Credit Information}

The development of Internet finance has produced a considerable number of Internet financial institutions and a large number of user groups, which poses a brand new challenge to the risk control of Internet financial institutions. [5]If Internet financial institutions still collect and analyze personal credit data alone, they not only will greatly reduce the efficiency of financial operation, but also lead to a significant increase in the incidence of credit risk. In order to solve this problem, Internet financial institutions will inevitably reach a personal credit data sharing mechanism to control personal credit risk effectively while reduce the cost of Internet finance operations.

\section{Construction and Experience of American Personal Credit Investigation System}

\section{American Personal Credit Investigation System Construction}

The current system of credit investigation in the United States is obviously divided into two types: one is credit investigation by agencies and the other is personal credit investigation. Each credit investigation system has a relatively independent operation agency. In the construction of personal credit investigation system, American personal credit market started when the first credit bureau established by Brooklyn in the 1860s. After several hundred years of development, the personal credit market in the United States has now formed a sound personal credit system with big credit bureaus at the core which respectively are Experian, Equifax and TransUnkm. Currently, these big credit bureaus cover almost all adult population in the United States, and more than hundreds of millions of credit reports are provided per year. Figure 1 is American personal credit business chain map.

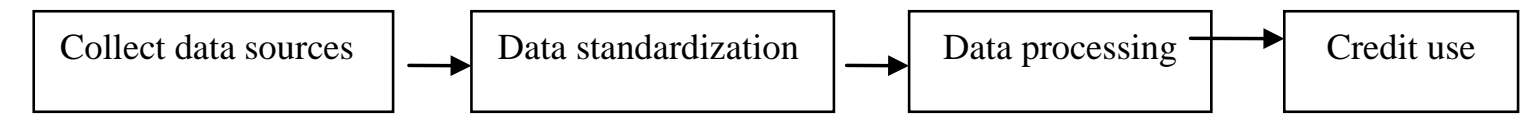

\begin{tabular}{|c|c|c|c|c|}
\hline $\begin{array}{l}\text { Financial institutions } \\
\text { Public information } \\
\text { Local credit company } \\
\text { Public utility } \\
\text { Telecom operators } \\
\text { Criminal record }\end{array}$ & $\begin{array}{l}\text { METRO } 1 \\
\text { METRO } 2\end{array}$ & $\begin{array}{l}\text { Experian } \\
\text { Equifax } \\
\text { Trans } \\
\text { Union }\end{array}$ & $\begin{array}{l}\text { FICO Score } \\
\text { Vantage Score } \\
\text { Credit Report }\end{array}$ & $\begin{array}{l}\text { Financial institutions } \\
\text { Credit card application } \\
\text { Employer business } \\
\text { Personal loans } \\
\text { Federal government } \\
\text { Public service agencies }\end{array}$ \\
\hline
\end{tabular}

Figure 1 American personal credit business chain

Personal credit information collected includes three categories: one is personal identity information, the second is personal credit information which is the most important, and the third is the public information that can be obtained. Some of this information is collected by the credit bureaus free of charge and some are collected through payment to other agencies. It is of crucial importance to maintain good cooperation with relevant agencies and enterprises in collecting information. Through the collection of disorganized data, credit bureaus need to standardize their 
data to apply the data to the mode. In the course of using the result of credit information, special attention needs to be paid to the protection of the privacy of personal credit information. The calling information needs the consent of the parties concerned and the relevant departments so as to prevent the abuse of personal information.

\section{The Supervision System Construction of American Personal Credit Investigation System}

In the process of personal credit information services in the United States, the main function of the government is to supervise and manage the use of laws instead of participating in specific issues such as data collection, mode design and product development. Judicial supervision, administrative supervision and industry self-regulation together form the supervision and management system of personal credit investigation in the United States. Among them, the Federal Trade Commission is responsible for the supervision and administration of individual credit investigation agencies, consumer credit providers and consumer agencies, while the Federal Reserve System supervises banking institutions and courts at all levels are responsible for the judicial supervision of banks.

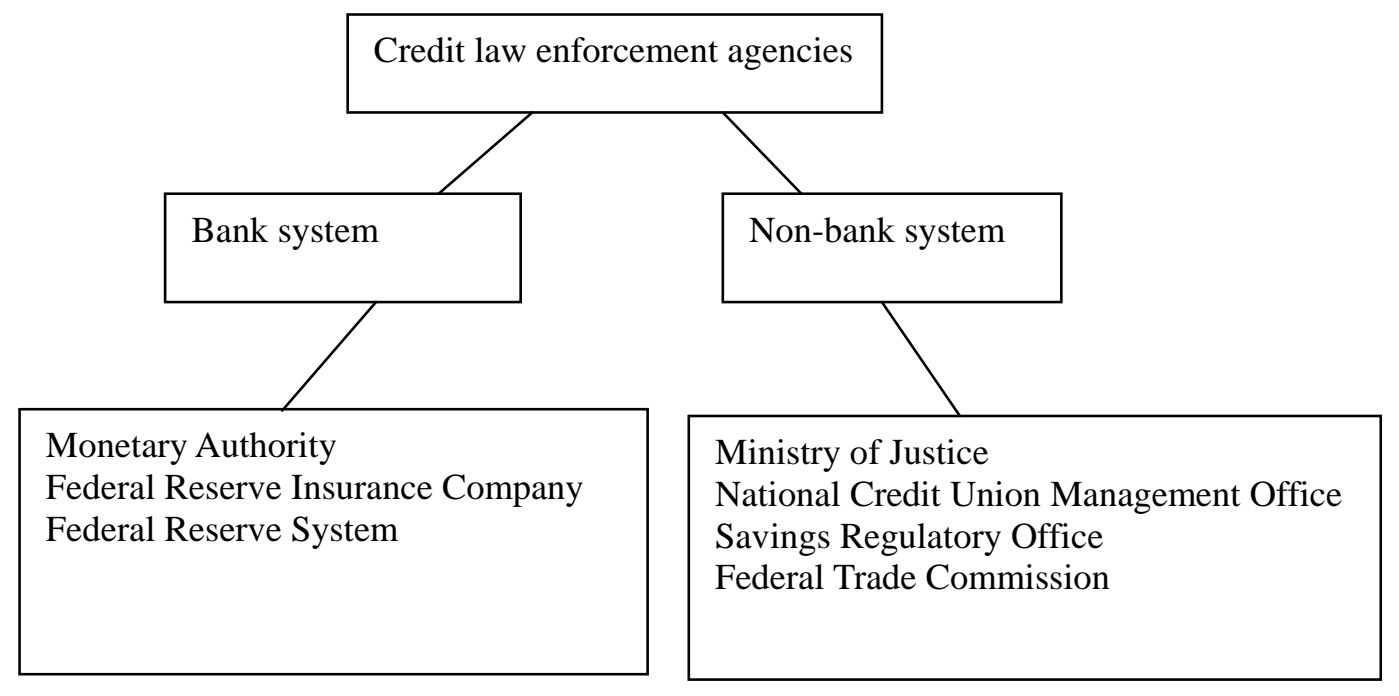

Figure 2 American supervision and management framework of personal credit investigation

\section{The Ideal Mode Construction of China's Big Data Internet Financial Personal Credit Investigation System}

Based on the above analysis and construction principles of a variety of Internet personal credit investigation systems, by combining the current development of Internet finance and personal credit investigation system in China, the ideal mode should be based on the system of People's Bank of China and establish Internet finance subsystem. The constructed Internet financial one, the traditional one and the public information personal credit investigation system will form the complete personal credit investigation system in China together, such as Figure 3 below: 


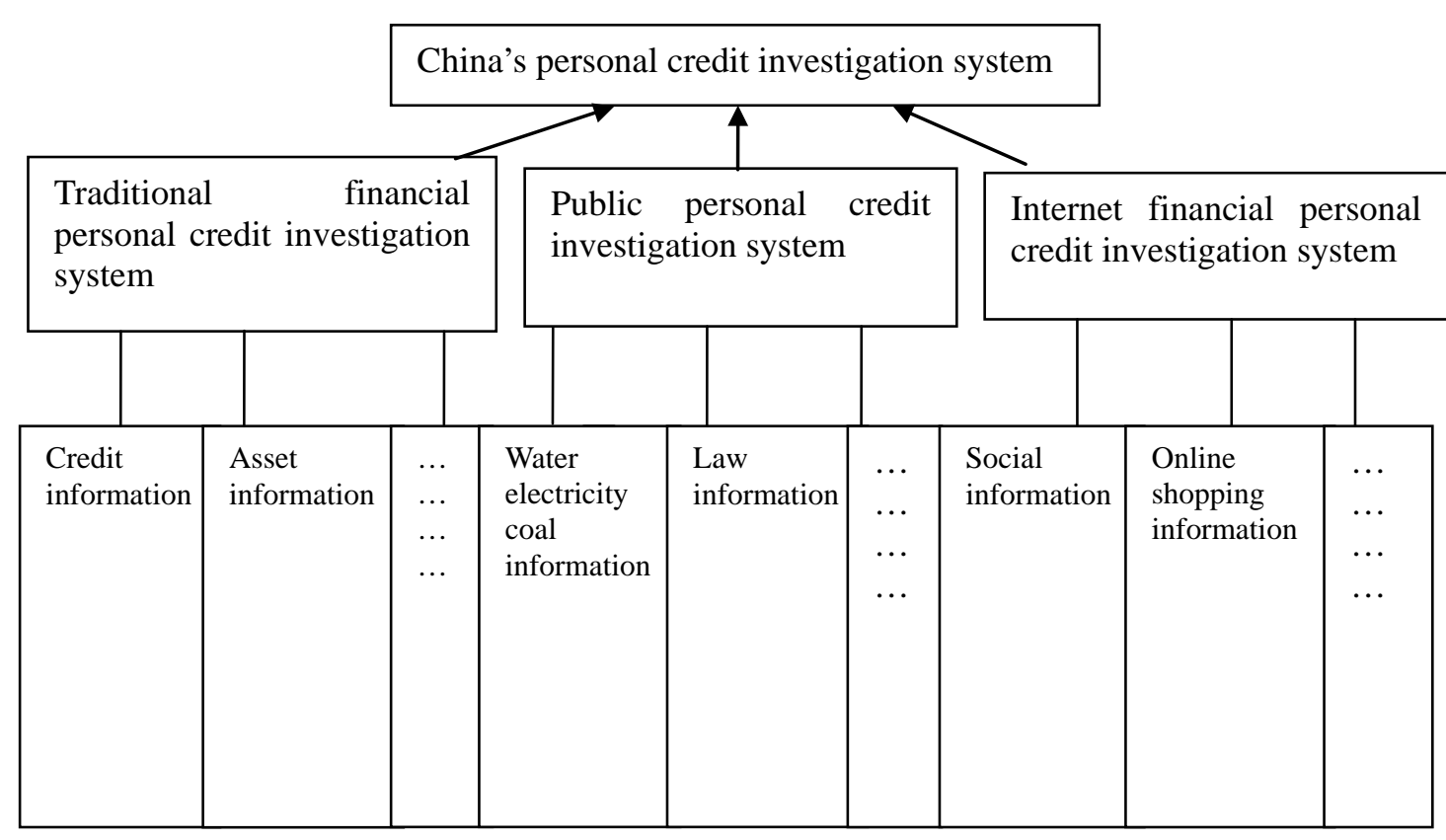

Figure 3 The Mode of China’s Big Data Internet Finance Personal Credit Investigation System

Internet financial personal credit subsystem consists of three parts.

\section{The Source of Personal Credit Data Collection}

We can classify the patterns of internet finance into five main categories: big data finance, internet financing, third-party payment, financial institution informatization and internet finance portal. Big data finance mainly refers that e-commerce sites rely on a large number of users accumulated by the site, through the grasp of massive personal credit data to carry out financial services. The most typical example is Alibaba Group which through the huge amounts of personal credit data accumulated by Taobao, Tmall and Alibaba and other platforms to develop Alipay, Yu'E Bao and Alibaba loan and other Alibaba financial services; Internet financing refers mainly to P2P lending and crowd funding, since P2P lending and crowd funding have low starting points for investment, so there will be a large number of investment groups which means a huge amount of personal credit data; Third-party payment refers to the electronic payment mode in which some non-bank institutions with certain strength and reputation guarantee establish a connection between the bank and the user's payment and settlement system by using Internet-related technologies, such as Alipay, E-commerce, WeChat payment, etc.. The informatization of financial institutions mainly refers that the traditional financial institutions through the Internet-related technology do some information processing of its traditional operation mode to meet the operational needs of the new era; Internet financial portal mainly refers to the service portal that can collect financial information and provide financial information search. They are only intermediaries to provide financial information, not financial services. In these five types of Internet financial modes, big data finance, Internet financing and third-party payment can be used as the source of personal credit data collection. The informatization of financial institutions should be included in the traditional personal credit investigation subsystem to collect personal credit data, which is not be needed here. And the Internet financial portal is only the provider of financial information, which has no substantive significance for personal credit investigation.

\section{Transitional Platform of Personal Credit Investigation}

Because there are differences in the collection, collation and analysis of personal credit data of Internet financial platforms, so is the personal credit investigation system of the People's Bank of China, therefore, it is necessary to build a transitional platform for personal credit investigation. Through the transitional platform, Internet finance platform step by step integrates into the personal credit investigation system and ultimately build Internet financial personal credit investigation 
subsystem based on the transition platform. The transition platform can be built in two ways: setting up a new transitional organization or using an existing third-party credit investigation agency as a transitional platform. The author holds that using the existing third-party credit investigation agencies as a transitional platform is more reasonable, because setting up a new transition platform takes a lot of manpower, material and financial resources and time, meanwhile, the existing third-party credit reporting agencies has already equipped with certain amount of technology and resources after such a long period of development, so it is more suitable to be a transitional platform.

\section{Composition of Personal Credit Products}

The so-called credit products refer to the credit information services that credit agencies provide to consumers. Internet financial personal credit subsystem can provide personal credit information products and personal value-added credit products. Personal credit information products mainly refer to the personal credit report. Personal credit report should contain three aspects of information: personal basic information (name, ID number, phone number, address, marital status, etc.), personal credit transaction information (loan information, investment information, repayment information, etc.) and others information (inquiry record, inquiry organization, etc.) Personal credit report is only an objective record of personal credit data, if there are further processing of these objective personal credit data, they formed a personal value-added credit products. Personal value-added credit products, including personal credit score, mining and cleaning of big data, personal credit card personalization services, etc., of which the most important is the personal credit score. Personal credit score is the quantification of personal credit status, which can be more intuitive to determine the personal credit status and more conducive to credit risk control.

\section{Conclusion}

Internet finance has developed rapidly in China in recent years, and the inclusive nature of Internet finance has determined that it is more extensive than the traditional financial industries. In the internet finance background, big data personal credit investigation method should be adopted. The development of Internet finance makes the personal credit data increase in volume with more sources and more extensive dimensions, which are far beyond the scope of the traditional personal credit investigation methods. So it is necessary to use the big data personal credit investigation method, which can make the processing speed faster, the process more convenient and the results more accurate. According to China's national conditions and foreign experience, the ideal mode of China's Internet financial personal credit investigation system should be based on the personal credit investigation system of the People's Bank of China, and meanwhile establishes an internet financial personal credit investigation subsystem.

\section{References}

[1] Big data based fraud risk management at Alibaba[J] . Jidong Chen,Ye Tao,Haoran Wang,Tao Chen. The Journal of Finance and Data Science . 2015 (1)

[2] Credit Risk Prediction Using Fuzzy Immune Learning[J] . Ehsan Kamalloo,Mohammad Saniee Abadeh,M. Onder Efe. Advances in Fuzzy Systems . 2014

[3]Credit scoring by feature-weighted support vector machines[J] . Jian Shi,Shu-you Zhang,Le-miao Qiu. Journal of Zhejiang University SCIENCE C . 2013 (3)

[4] Is innovation always good?. LUC SOETE. Innovation Studies . 2013

[5] A hybrid KMV model, random forests and rough set theory approach for credit rating[J] . Ching-Chiang Yeh,Fengyi Lin,Chih-Yu Hsu. Knowledge-Based Systems . 2012 